\title{
„Nová stredná Európa" u Tomáša G. Masaryka, Friedricha Naumanna a Milana Hodžu
}

\section{The "New Central Europe" of Tomáš G. Masaryk, Friedrich Naumann and Milan Hodža}

Dušan Kováč / kovac@up.upsav.sk

Historický ústav, Akademie vied Slovenskej republiky, Bratislava, SK

\begin{abstract}
This study is a contribution to the lively discussion over the past twenty years comparing the ideas formed by T.G. Masaryk, Friedrich Naumann and M. Hodža during the First World War. The author mainly focuses on comparing ideas from their key well known publications (Masaryk's The New Europe, Naumann's Mitteleuropa, Hodža's Federation in Central Europe). He states that all three politicians agreed that Europe in the future had to be democratic, but their specific ideas about its character and about the importance of nation states differed. Naumann's plan was to create a democratic Central Europe under German leadership, which Masaryk and Hodža refused outright.
\end{abstract}

\section{Keywords}

Central Europe, Europe, T. G. Masaryk, F. Nauman, M. Hodža, centralism, federalism, the First and the Second World War. 
Kniha Friedricha Naumanna Mitteleuropa ${ }^{1}$ vzbudila mimoriadnu pozornost’ hned' po svojom vyjdení v roku 1915 a až do súčasnosti púta pozornost' bádatel’ov prakticky na celom svete. Historikov i politológov v strednej Európe láka okrem toho porovnanie Naumannovej koncepcie s koncepciou Tomáša G. Masaryka, predovšetkým s jeho knihou Nová Evropa ${ }^{2}$ Iba za posledných dvadsat rokov vyšlo na túto tému množstvo článkov, štúdií, konali sa vedecké sympóziá. ${ }^{3}$ Iba časopis Bohemia priniesol na prelome storočí k tejto téme tri zaujímavé štúdie. ${ }^{4} \mathrm{Z}$ nemeckých historikov sa téme venoval opakovane Rudolf Jaworski. ${ }^{5}$ Téma lákala aj českých historikov. Ešte v 60-tých rokoch sa Naumannovi venoval Zdeněk Jindra ${ }^{6}$ a Friedrichovi Naumannovi a jeho Mitteleurope Václav Houžvička. ${ }^{7}$ Priamo porovnaniu Naumannovej a Masarykovej koncepcie v diele Nová Evropa je venovaná štúdia Evy Broklovej. ${ }^{8}$ Určitým problémom v staršej i novšej českej historiografii je, že sa v nej v ovela menšej miere ako v literatúre nemeckej, či zahraničnej tematizuje miesto Friedricha Naumanna v nemeckej spoločnosti. Niekedy potom vyzerá aj jeho koncepcia Mitteleuropy plocho a nie je vidiet’ rozdiel medzi V̌̌enemcami (Alldeutsche) a liberálno-demokratickými nemeckými nacionalistami. Ak si uvedomíme, že Friedrich Naumann je politik a intelektuál presadzujúci demokraciu v nemeckom prostredí (podobne ako Tomáš G. Masaryk v prostredí českom a slovenskom) a pritom považoval nemeckú supremáciu v Európe za prirodzenú, pochopíme celú zložitost̉ spoločenského diskurzu v Nemecku počas prvej svetovej vojny, po nej a napokon v určitom zmysle aj v súčasnosti.

1 Naumann, Friedrich: Mitteleuropa. Berlin 1915. Kniha sa dočkala dalších vydaní a stala sa jednou z najčítanejších kníh počas vojny v Nemecku.

2 Masaryk, Tomáš Garrigue: Nová Evropa. Stanovisko slovanské. Praha 1920, s. 56-57.

3 Kárník, Zdeněk: T. G. Masaryk a Friedrich Neumann - dva koncepty pro Evropu: úvodni slovo k vèdeckému symposiu českých a německých historiků a studenti̊. Studia territorialia. Studia germanica et austriaca. Katedra německých a rakouských studií IMS FSV UK 1. Praha 2001 [vyd. 2002], s. 93-115; Kropáček, Jiř́i : „Středni Evropa " "T. G. Masaryka a jiných státnikio a politiki̊ za pruni světové války. In: T. G. Masaryk a střední Evropa. Materiály z konference Masarykovy univerzity v Brně 5. - 6. června 1991. Red. R. Pražák. Brno 1994, s. 101-107.

4 Hahn, Hans Henning : T. G. Masaryks „Neues Europa“ und F. Naumanns „Mitteleuropa“: ein bilaterales Studienprojekt. Bohemia. Zeitschrift für Geschichte und Kultur der böhmischen Länder 39, 1998, s. 443-445; Rühmkorf, Christian: „Volkswerdung durch Mythos und Geschichte“: die deutsch-slawischen Beziehungen bei Friedrich Naumann und T. G. Masaryk. Bohemia : Zeitschrift für Geschichte und Kultur der böhmischen Länder 41, 2000, s. 295-325; Breder, Jens: Die Rolle Russlands in den Europa-Konzeptionen von Friedrich Naumann und Tomáš Garrigue Masaryk. Bohemia : Zeitschrift für Geschichte und Kultur der böhmischen Länder 41, 2000, s. 343-363.

5 Jaworski, Rudolf: Friedrich Naumann a Češi. In: První světová válka a vztahy mezi Čechy, Slováky a Němci. Eds. H. Mommsen - D. Kováč - J. Malíř - M. Marková. Brno 2000, s. 195-206; Jaworski, Rudolf: Tomáš G. Masaryk versus Friedrich Naumann. Zwei Europavisionen im Ersten Weltkrieg. In: Occurcus - setkání Begegnung. Sborník k poctě 65. narozenin prof. dr. Jana Křena. Eds. Z. Pousta - P. Seifer - J. Pešek. Praha 1996, s. 123-134.

6 Jindra, Zdeněk: Der Plan der deutschen Hegemonie in Mitteleuropa. In: Beiträge zur neuesten Geschichte der mitteleuropäischen Völker. Eds. Z. Jindra - J. Kř́žzek. Praha 1960.

7 Houžvička, Václav: Mitteleuropa - vize dominujicino Německa. In: Spory o dějiny. Sborník kritických textů. Sv. IV. Ed. M. L. Neudorflová. Praha 2003, s. 84-98.

8 Broklová, Eva: Masarykova Nová Evropa a Naumannova Mitteleuropa. In: Evropanství a Tomáš Garrigue Masaryk. Sborník příspěvků ze 6. ročníku semináře Masarykova muzea v Hodoníně 18. listopadu 1998. Ed. T. Martonová. Hodonín 1999, s. 43-55. 
Napriek bohatej literatúre, ktorá nepochybne obsahuje množstvo pozoruhodných záverov a myšlienok, je téma porovnania Masarykovej a Naumannovej koncepcie stále aktuálna. Pokúsil som sa rozšírit doterajší obzor o stredoeurópsku koncepciu slovenského politika Milana Hodžu. Nakol'ko Hodža už zažil Mníchov a prvé roky druhej svetovej vojny, môže byt jeho dielo Federácia v strednej Európe produktívnym rozšírením témy. Pokúsil som sa o komparáciu Masaryka, Naumanna a Hodžu predovšetkým v otázkach ako vnímali vztah strednej Európy k Európe ako celku, aká teda bola ich predstava novej Európy, ako vnímali budúci politický systém v Európe, ako sa pozerali na miesto a úlohu malých národov a aké miesto zastávali ich koncepcie vo vztahu k nacionalizmu a „národnému štátu“. Považoval som za užitočné vychádzat nielen z troch hlavných diel, ale rozšírit pohlad o postoje v širšom historickom období - teda pred vojnou, resp. po vojne. Takéto rozšírenie spektra nám umožňuje nevnímat iba literu napísaného, ale vidiet’ veci v širšom historickom kontexte. Masaryk, Naumann a Hodža v niektorých otázkach predišli svoju dobu, ale v mnohých d’alších otázkach boli svojou dobou pochopitelne ovplyvnení.

Myšlienka trvalejšieho európskeho usporiadania, súčastou ktorého boli aj koncepcie Strednej Európy sa objavovali už od stredoveku. V moderných dejinách, teda od 19. storočia, politika európskych štátov, predovšetkým vel’mocí, bola priamo posadnutá formovaním rôznych koncepcií, koalícií a zoskupení štátov. Východiskom pre medzinárodnú politiku v 19. storočí boli rokovania a závery Viedenského kongresu. Francúzska revolúcia z rokov 1789-1794, napriek gilotíne a prechmatom novej moci, priniesla do európskej politiky novú dynamiku a Napoleon Bonaparte, aj ked’ už ako cisár, rozniesol výdobytky francúzskej revolúcie, predovšetkým Code civil, ideu rovnosti občanov vyjadrenú v Deklarácii práv človeka a občana, rozšírenie volebného práva a niektoré d’alšie revolučné výdobytky po celej Európe. Usiloval sa tak Európu zjednotit a zorganizovat pod svojím žezlom. Napoleonova expanzia mala na Európsku spoločnosṫ dvojaký vplyv. Na jednej strane bolo vo všetkých štátoch dost̉ ludí, ktorým nové poriadky boli sympatické a vyjadrovali aj ich predstavy o zreformovanej Európe. Ale na druhej strane sa v mnohých krajinách, už aj v dôsledku prebúdzajúceho sa nacionalizmu, prejavil odpor proti "francúzskym poriadkom". ${ }^{9}$ Napoleonské vojny súčasne názorne ukázali aká je Európa malá a ako v nej všetko navzájom súvisí.

V oblasti politických ideí ako reakcia na pokus Viedenského kongresu konzervovat stav, ktorý vznikol po porážke Napoleona, objavila sa na jednej strane idea „národného štátu“ a na druhej strane rôzne federalistické koncepcie celoeurópske, stredoeurópske i nemecké. $\mathrm{V}$ čase európskej nehybnosti po kongrese sa tieto idey prezentovali skôr v rovine teoretickej, akademickej, aj ked' predstavitelia novej, silnej, hlavne ekonomicky, spoločenskej vrstvy - meštianstva, boli zárukou, že pri zavedení konštitucionalizmu, dostanú sa tieto idey aj do sféry praktickej politiky. Konzervatívnym silám na Viedenskom kongrese sa napokon nepodarilo natrvalo znehybnit Európu. Oslobodzovacia vojna Grécka, nepokoje a revolúcie v rôznych krajinách, vyústili napokon predsa do novej revolúcie, ktorá v roku 1848 mala celoeurópsku dimenziu. Jediné, čo po Viedenskom kongrese

9 Pozri Rapport, Michael: Europa devatenáctého století. Praha 2011, s. 54-64. 
ostalo v trvalej platnosti takmer pre celé 19. storočie, bol koncert vel'mocí, ktorý bol dlho vstave zabránit príliš radikálnym a jednostranným zmenám.

Počas napoleonských vojen a následne po celé storočie bola Európa konfrontovaná s troma skutočnostami: s ruskou expanziou do Európy, s nevyriešenou nemeckou otázkou a s narastajúcim konfliktom Nemecka s Vel'kou Britániou a Francúzskom.

Roku 1812 sa ruské vojská po prvýkrát v dejinách prehnali celou Európou, po tzv. Bitke národov pri Lipsku roku 1813 im už nič nestálo v ceste a došli až do Paríža. Bola to po každej stránke skúsenost́. Pre dôstojníkov, obyčajných vojakov, ale aj pre cára a jeho kamarilu. V strednej Európe si vytvorilo Rusko v Pol’sku tzv. Kongresové vojvodstvo (Kongresovku). Odtial' napokon poslal ruský cár svoje vojsko na pomoc Františkovi Jozefovi, ktorý si nevedel poradit s mad’arským povstaním. Pozornosṫ Ruska sa následne obrátila na južné oblasti, kde takmer permanentným cielom ostávali čiernomorské úžiny a balkánske krajiny. Pre Európske vel’moci bolo Rusko vážnym spojencom proti Napoleonovi, ale aj potom v nasledujúcich rokoch ako významný člen Svätej aliancie. Napriek tomu sa ako Vel'ká Británia, tak aj Francúzsko, Prusko a, s určitým váhaním napokon aj Rakúsko, postavili proti d’alšej expanzii Ruska do Európy a do Stredomoria. Ukázalo sa to jednak počas Krymskej vojny (1853-1856) a aj počas intervencie Ruska v čase balkánskych oslobodzujúcich povstaní v poslednej tretine 19. storočia, ked’ Berlínsky kongres v r. 1878 zabránil Rusku, aby zúročilo svoje vojenské vítazstvá proti Turecku. Ruská invázia do Európy ostala pre európske velmoci traumou a permanentným nebezpečenstvom.

Druhým vážnym problémom Európy 19. storočia bola nemecká otázka. Po zániku Svätej ríše rímskej nemeckého národa roku 1806 v dôsledku porážok od Napoleona, vzniklo Rakúske cisárstvo a Nemecký spolok (Deutscher Bund). Bola to volná federácia, v ktorej dominantú úlohu hrali Rakúsko a Prusko. Tieto štáty navzájom súperili o vedúce postavenie $\mathrm{v}$ nemeckom priestore, čo bolo na prekážku reálneho štátneho zjednotenia. Situácia, ktorá vznikla po prusko-rakúskej vojne a po vzniku Nemeckého cisárstva roku 1871 pod vedením Pruska vyradila síce napokon Rakúsko z nemeckého priestoru, ale neuspokojila zd’aleka všetkých, ktorí usilovali o štátne zjednotenie. Bismarckovo malonemecké riešenie považovali za provizórium nielen Všenemci (Alldeutscher Verband), ale aj nemeckí liberáli a demokrati. Aj tí, a jedným z ich predstavitelov bol aj Friedrich Naumann, považovali za samozrejmé, že Nemecko má v Európe svoje poslanie, že je to vel'ký štát, ktorý musí niest’ za Európu aj svoj diel zodpovednosti. Uväznení v hraniciach Bismarckovho Nemecka, hladali spôsoby, ako rozšírit nemecký vplyv na celý kontinent, Nemecko, skrátka nemohlo ostat’ v svojich hraniciach, ale malo úlohu organizovat strednú Európu a Európu vôbec. Všenemecký zväz vystupoval agresívne, nemeckí liberáli hl’adali cesty „prirodzeného“ rozšírenia nemeckého vplyvu s pomocou ostatných národov.

Nemecké cisárstvo ako nová vel’moc usilovalo o hegemóniu na kontinente a dostalo sa tak do potencionálneho konfliktu s Francúzskom, ktoré sa nezmierilo s odstúpením, Alsaska-Lotrinska a hladalo cesty odvety za prehratú vojnu z roku 1871. Nemecko súčasne usilovalo o kolónie v Afrike a v Ázii, začalo s výstavbou vojnového lod’stva. To všetko iritovalo Vel'kú Britániu, ktorá cítila, že Nemecko usiluje zlomit britskú dominanciu na svetových moriach. 
Tieto problémy, ktoré vznikli v 19. storočí, preniesla si Európa aj do storočia nasledujúceho. Každý, kto sa zaujímal o politiku a o budúcnost’ Európy, musel s touto globálnou situáciou počítat. Stredná Európa, predovšetkým jej východná čast', pretože Nemecko sa cítilo byt súčastou strednej Európy tiež, po podpísaní dvojspolkovej zmluvy medzi Nemeckom a Rakúsko-Uhorskom roku 1879 dostala sa tak pod silný nemecký vplyv politický i ekonomický. Nie všetkým národom a nie všetkým politikom takáto situácia vyhovovala. Narastajúca kríza, ktorá hrozila konfliktom medzi Dvojspolkom (od roku 1882 po pristúpení Talianska Trojspolkom) a Dohodou, reprezentovanou na východe Ruskom a na západe tzv. západnými vel’mocami - Francúzskom a Vel'kou Britániou, nútila politikov, vrátane politikov malých národov, k úvahám o možnej budúcnosti malých národov. K takým politikom patrili ešte pred prvou svetovou vojnou aj Tomáš G. Masaryk a Milan Hodža. Na nemeckej strane sa otázkou budúcnosti strednej Európy najintenzívnejšie zaoberal práve Friedrich Naumann.

Najstarším zo skúmanej trojice je Masaryk (1850), Naumann bol o desat’ rokov (1860) a Hodža o celú generáciu (1878) mladší. Počas prvej svetovej vojny každý z nich sledoval určité politické ciele. Naumann sa stal vlastne vd’aka vojne slávnym. Roku 1915, teda v druhom roku vojny, publikoval svoje dielo Mitteleuropa, ktorému vlastne vojna dala nový zmysel a novú dimenziu, pretože je to vlastne dielo o prehlbovaní spojenectva medzi dvoma Ústrednými vel’mocami. Masaryk už na začiatku vojny emigroval a v zahraničí začal organizovat československý odboj s ciel’om vytvorenia samostatného československého štátu. Už z tohto dôvodu sa Masaryk stal odporcom Naumanna a jeho ideí. Ak Masaryk chcel, aby vel'moci Dohody akceptovali plán vytvorenia československého štátu, musel svoju koncepciu postavit na zlomení moci Nemecka, ktoré bolo pre Vel'kú Britániu i Francúzsko hlavným nepriatel'om. Rakúsko-Uhorsko sa vnímalo iba ako slabší nemecký spojenec. Preto je Masarykova rétorika silne protinemecká a jeho argumenty vždy mierili k tomu, že zánik Rakúsko-Uhorska a vytvorenie nástupníckych štátov na východných nemeckých hraniciach vytvorí účinnú bariéru nemeckému Drang nach Osten. Masaryk Naumannovu knihu ani nereflektoval, v knihe Světová revoluce nie je o Naumannovi ani zmienka, v Novej Europe je spomínaná iba všeobecne nemecká „Stredná Evropa“10 Naumannove idey boli v priamom protiklade voči plánom Masarykovým.

Friedrich Naumann povzbudený úspechom svojej knihy, pokúšal sa jej idey aj uvádzat do praxe, cestoval po Rakúsko-Uhorsku , stretával sa s politikmi rôznych národov a pokúšal sa ich presviedčat’ o výhodnosti a zmysluplnosti svojej Mitteleuropy. Tak sa v októbri 1915 stretol s Milanom Hodžom a v marci 1916 s poprednými českými politikmi. ${ }^{11}$ Hodža svoje stretnutie s Naumannom v svojej publicistike nekomentoval, k Naumannovi sa vrátil až na konci vojny, ked' sa rokovalo o nemecko-rakúsko-uhorskej colnej únii a Naumann patril k jej najväčším propagátorom. Hodža ho síce považoval za dobrého rečníka, ale nedával mu nijakú nádej na to, že niekoho presvedčí: Nikto ju nechce, a predsa je Stredná Európa „už na ceste, ba, povedal ktorýsi nemecký štátnik, „už je hotová“....Nám národom ešte nehotovým, rastúcim a zápasiacim o podmienky vlastného politicko-národného a hospodárskeho

10 Masaryk, T. G.: Nová Evropa, s. 56-57.

11 Tobolka, Zdeněk Václav: Politické dějiny Československého národa od r. 1848 až do dnešni doby. Díl IV. 19141918. Praha 1937, s. 84. 
dovřrsenia, je národne-politický individualizm ako vzduch, bez ktorého nemožno nielen rozvíjat' sa, ale ani len vydýchnut' a žit'. My nemôžeme sa podčinit’ medzinárodnej discipline v novom svetovom hospodárstve, lebo to by bolo súručenstvom všetkých navzájom; ale nemôžeme sa obetovat' mocným, vykoristovatelom. To jest: Prečo len „Stredná Európa?" Prečo nie „Celá Európa?" Prečo nie už potom celý vzdelaný Svet? ${ }^{12}$

Milan Hodža vnímal strednú Európu úplne odlišne ako Naumann. Preňho bola stredná Európa priestorom medzi Nemeckom a Ruskom, teda bolo to pásmo malých štátov a malých národov, ktoré práve, ak chcú prežit, efektívne zúročit svoj vlastný potenciál, potom sa musia spojit, federalizovat', aby vytvorili priestor, ktorý by bol schopný odolat politickému i ekonomickému vplyvu velkých, predovšetkým vel'kých susedov - Ruska a Nemecka. Takáto predstava zbližuje Hodžu do určitej miery s Masarykom, ktorý tiež videl budúcnosť československého štátu v úzkej kooperácii so susedmi. Napriek tomu je zaujímavé sledovat a komparovat' zásadné politické postoje týchto troch politikov i politických teoretikov.

Vzhladom na celkovú orientáciu a politický program Masaryka, Naumanna a Hodžu je jasné, že ich programy sa v mnohých ohladoch priamo vylučovali. $\mathrm{V}$ jednom bode sa však predsa stretli: v skeptickom postoji ku koncepcii „národného štátu“. Možno toto konštatovanie môže byṫ problematické vo vzṫahu k Masarykovi a do určitej miery aj voči Hodžovi. Masaryk bol tvorcom koncepcie československého národného štátu a počas vojny tvrdo a húževnato bojoval za uskutočnenie tohto plánu. Ked'sa však pozrieme na celú jeho politickú dráhu, môžeme konštatovat', že vstúpil do politiky ako nekompromisný kritik programu „obnovy českej štátnosti“. V českom štáte, či už v rámci Habsburskej monarchie, alebo mimo tohto rámca nevidel zmysel a perspektívu. Reálnejšia sa mu zdala byt Palackého „idea štátu rakúskeho“. Ako poslanec sa však postupne presvedčil o tom, že Habsburská monarchia je takým komplikovaným a neperspektívnym útvarom, že hned' na začiatku vojny predložil Dohode prostredníctvom britského ministerstva zahraničných vecí program vytvorenia československého štátu. Masaryk ale od samého začiatku považoval za žiadúce, aby sa štáty a národy neizolovali, ale spájali. Aj budúce Československo videl v tejto perspektíve, ale predpokladom spájania a federácie bola preňho sloboda. Cesta $\mathrm{k}$ federalizacii v Európe a aj v strednej Európe viedla najprv cez oslobodenie všetkých, predovšetkým malých národov: Skutečná federace národů nastane teprve, až národové budou volni a sami se spoji. K tomu směruje vývoj Evropy. Program spojenců plně odpovídá tomuto vývoji: svobodni a osvobozeni národové zorganizuji se podle potřeby ve větši celky a zorganizuje se tím celý kontinent. Vzniknou-li federace menšich států, budou to federace svobodně založené, založené z opravdové potréby národi̊, nikoli z cíli dynastických a imperialistických ${ }^{13}$.

Rovnako Milan Hodža chápal, že slovenská otázka sa môže perspektívne riešit iba v širších, prinajmenšom stredoeurópskych väzbách. Bol kritický voči prílišnému ruskému mesianizmu martinských predstavitelov Slovenskej národnej strany. Považoval plán federalizácie Habsburskej monarchie, ktorý pre Františka Ferdinanda vypracoval vedúci

12 Hodža, Milan: Stredná Europa. In: Hodža, Milan: Články, reči, štúdie. Sväzok II. Československá súčinnost? 1898-1919. Praha 1930, s. 298-299.

13 Masaryk, T. G.: Nová Europa, s. 88. 
jeho belvederskej kancelárie major Alexander von Brosch-Aarenau za krok, ktorý by mohol byṫ riešením problému malých stredoeurópskych národov. Po zavraždení Františka Ferdinanda stal sa Hodža stúpencom vytvorenia spoločného československého štátu, pretože v Habsburskej monarchii už nevidel možnosṫ zásadnej reformy. Nový štát mal byt národným štátom, ale československý národ vnímal Hodža predovšetkým ako národ politický. A budúcnoste československého štátu videl Hodža v úzkej kooperácii malých stredoeurópskych štátov a $\mathrm{v}$ ich postupnej federácii, ktorá by zabránila tomu, aby sa $\mathrm{v}$ tomto priestore presadzovali vel'moci.

Friedrich Naumann bol kritikom Bismarckovho malonemeckého riešenia, ale bol tiež kritikom koncepcie vytvorenia velkého Nemecka (teda vrátane Rakúska). Národný štát, akokolvek vel'ký, bol pre Naumanna priestorom príliš úzkym a limitujúcim. Už v roku 1905 sa v svojich prednáškach, ktoré vydal knižne vyjadroval v tom zmysle, že Bismarckovo malonemecké riešenie mohlo byt dobrým riešením pre danú dobu, nebolo ale riešením všetkých nemeckých problémov pre budúcnost. Už vtedy považoval za nemecké poslanie organizovat Európu. ${ }^{14} \mathrm{Aj}$ pre Naumanna teda predstavoval „národný štát“ obmedzenie, ktoré je treba prekonat. Ako liberál však, na rozdiel od agresívnych Všenemcov, zdôrazňoval, že proces organizovania Európy sa mal uskutočnit cestou dohôd a rokovaní, v ktorých však malo mat Nemecko iniciatívu ako najvýznamnejšia európska (kontinentálna) velmoc.

Vypuknutie prvej svetovej vojny bolo pre Masaryka, Naumanna i Hodžu udalostou, ktorá mala rozhodovat o budúcej podobe Európy. Masaryk, ako je známe, hned’ v prvých mesiacoch vojny vypracoval plán vytvorenia československého štátu. Tento plán, sformulovaný najprv v októbri 1914 v tzv. Rotterdamskom memorande ${ }^{15}$ a neskôr, v máji 1915 v memorande Independent Bohemia, ${ }^{16}$ bol reálny iba za predpokladu, že vojna skončí vítazstvom Dohody. Masaryk vychádzal z vlastnej analýzy, že Nemecko a Rakúsko-Uhorsko vojnu prehrajú, ak táto bude trvat dlho. V každom prípade malo zmysel íst́ do odboja proti Habsburgovcom, pretože akékolvek ústupky bolo od Viedne možno získat́ nie prejavmi lojality, ale odbojom. To bola už Masarykova skúsenosṫ ako politika. Tak vlastne Masaryk začal presadzovat’ v zahraničí koncepciu československého štátu, ale vnímal ju nie izolovane, ale ako súčast’ velkých premien nielen v Európe, ale vo svete vôbec. Nový národný štát národa československého sa mal stat súčastou „svetovej revolúcie“. ${ }^{17}$ Hodža, ktorý počítal s tým, že František Ferdinand uskutoční svoj plán federalizácie monarchie, aj ked' si uvedomoval zložitosṫ takého projektu, musel po sarajevskom atentáte hladat iné možnosti riešenia slovenskej otázky. Ked’že bol ako vojak pridelený do Viedne do oddelenia cenzúry vojnovej korešpondencie a bol tak v dobrom kontakte s českými politikmi

14 Naumann, Friedrich: Die Politik der Gegenwart. Wissenschaftliche Vorträge gehalten in Hamburg und Heidelberg. Berlin-Schöneberg 1905.

15 Originál je v National Archives London, Public Record Office, f. Foreign Office 371/1900, 115-124. Tento dôležitý dokument je otištěný v: R. W. Seton-Watson and His Relations with the Czechs and Slovaks. Documents 1906-1951. I. Eds. J. Rychlík- T. D. Marzik - M. Bielik. Praha, Martin 1995, s. 209, dok. č. 61.

16 Originál dokumentu in National Archives London, Public Record Office, Foreign Office 371, 2241, $97-103$.

17 Masaryk, Tomáš Garrigue: Světová revoluce. Za války a ve válce 1914-1918. Praha 1925. 
i predstavitelmi iných národov, mal informácie aj o Masarykovom zahraničnom odboji, stal sa stúpencom idey československého štátu a mohol pre ňu aj vo Viedni, hlavne potom, ked’ nový cisár Karol zvolal ríšsky snem, intenzívne pracovat. Friedrich Naumann publikoval roku 1915 svoju knihu o Mitteleurope a stal sa zo dňa na deň jedným z najviac čítaných a najviac komentovaných autorov. Jeho kniha bola pôvodne o prehlbovaní spojenectva Nemecka a Rakúsko-Uhorska, ale postupne, počas vojny Naumann ako aktívny publicista začal rozširovat̉ priestor Mitteleuropy. V roku 1917 publikoval články Bulgarien und Mitteleuropa a Wir und Polen, ktoré dokumentujú, že z pôvodnej Mitteleuropy sa stávala „Grösseres Mitteleuropa“. Stúpenci Naumannovej vízie išli často d’alej než sám autor Mitteleuropy.

Naumannova kniha sa považovala za produkt vojny. V určitom zmysle to produkt vojny bol, ale idey, ktoré kniha predkladala, sa v nemeckom prostredí postupne rodili už od roku 1871, teda od dátumu zjednotenia Nemecka. Toto Bismarckovo malonemecké zjednotenie s vylúčením Rakúska, narazilo na tvrdú kritiku v Rakúsku i v Nemecku. Napriek kritike však zjednotenie iniciovalo aj diskusie o úlohách nového štátu, o jeho poslaní, o tom, že je to síce „národný štát“, ale jeho poslanie musí byṫ ovel’a širšie a nielen európske. Hovorilo a písalo sa o mieste na slnku (Platz an der Sonne), aj tí najliberálnejší myslitelia boli presvedčení, že na európskom kontinente je Nemecko povolané hrat úlohu lídra. V tomto smere sa prezentovali myslitelia ako Friedrich Liszt, Konstantin Frantz, či „učitel' Všenemcov" Paul de Lagarde. Diskusie o budúcnosti a poslaní Nemecka sa od samého začiatku uberali dvoma smermi. Oba smery vychádzali z toho, že Nemecko má dôležité poslanie v Európe a že sa nemôže „uzatvorit“" do hraníc štátu. Jeden smer predstavovali agresívne a expanzionistické teórie, ktoré stavali na nemeckej sile a na nemeckej výlučnosti. Tieto idey napokon rozvinulo na konci 19. storočia všenemecké hnutie, z ideí ktorého čerpal aj Adolf Hitler. Druhý smer bol umiernený, ale vychádzal rovnako z poslania Nemecka a jeho úlohy v Európe budúcnosti. Tento smer presadzovali predovšetkým liberálni demokrati združení v liberálnej strane (Fortschrittliche Volkspartei), ktorej členom bol aj Naumann. Metaforicky a azda aj ironicky sa títo nemeckí liberáli zvykli označovat za „etických imperialistov“. Pokial' ide o jeho knihu, ani jej názov nebol v nemeckom politickom diskurze nový. Už roku 1895 Publikoval predseda Všenemckého zväzu Ernst Hasse knihu s názvom Grossdeutschlnad und Mitteleuropa. Ak sa teda „Mitteleuropa“ stala akýmsi politickým vlastníctvom Naumanna, bolo to iba preto, že roku 1915, vlastne ešte na začiatku vojny, bola svojím titulom i obsahom dobre načasovaná a padla v nemeckej spoločnosti na mimoriadne pripravenú pôdu. Preto je vel'mi užitočné vnímat Naumannovu knihu nie iba na základe jej vlastného textu, ale je užitočné ju sledovat’ v celkovej Naumannovej publicistike pred vojnou i počas vojny, ked' k myšlienke Mitteleuropy pridával v svojich d’alších článkov nové impulzy, ale kniha vychádzala v nezmenenom vydaní ako svedectvo o užitočnosti prehlbovania vojnového spojenectva dvoch Ústredných velmocí.

Celkom iný osud mal Masarykov spis Nová Evropa. Masaryk ho písal na konci vojny a bol zamýšlaný ako stručný výklad plánov a cielov zahraničného odboja predovšetkým pre československých legionárov. Mala to byt̉ teda akási príručka, ktorú už ale v hektike konca vojny Masaryk nestihol vydat. V Rusku v Československom Deniku vyšli časti rukopisu ešte v roku 1918, ale celé dielo sa publikovalo až po vojne v roku 1920. Na rozdiel 
od Světové revoluce, ide o spis stručný, hlavné myšlienky sú tu podané v kondenzovanej podobe. Ked’že kniha napokon vyšla až po vojne, dostalo sa jej nového poslania. Predstavuje výklad zmyslu a priebehu zápasu za československý štát. Dôležitým atribútom tohto výkladu je, že podobne ako v knihe Světová revoluce vidí boj Čechov a Slovákov za štátnu samostatnost’ v širokom európskom kontexte. Aj Masaryk sa usiloval vidiet’ vznik nového štátu nie iba ako projekt sám pre seba, či pre Čechov a Slovákov, ale usiloval sa naformulovat význam tohto štátu pre Európu, predovšetkým ako dôležitého predbojovníka demokratickej Európy.

Hodžova práca Federácia v strednej Európe ${ }^{18}$ bola napísaná v celkom inej dobe. Knihu napísal Hodža v angličtine a publikoval v Londýne. ${ }^{19}$ Nakol'ko zomrel v roku 1944, možno knihu chápat’ aj ako jeho politický závet, v ktorom zohladnil už aj skúsenosti z medzivojnového obdobia a prebiehajúcej vojny. Tento historický kontext posúva Hodžovu knihu, samozrejme, do iných súvislostí. V knihe však Hodža celú dlhú prvú kapitolu venoval obdobiu pred prvou svetovou vojnou a samotné vojnové obdobie úplne vynechal. Vychádzal z vlastných skúseností s politikou v Rakúsko-Uhorsku a to predovšetkým z toho, čo sa dialo v jej uhorskej časti. Federalizačné plány videl z pohl'adu na jednej strane malého stredoeurópskeho národa, ale na druhej strane aj z hladiska celoeurópskeho. Potreba širšej spolupráce v strednej Európe a vytvorenie v tomto priestore nadnárodného celku je u Hodžu motivovaná jeho geograficky chápanou strednou Európou ako priestorom medzi Nemeckom a Ruskom. Ideu nedovolit vel'mociam aby kontrolovali, či dávali nejaké záruky malým národom a štátom mal už Hodža potvrdenú aj osudom medzivojnového Československa a Mníchovskou dohodou. Riziko spoliehania sa na záruky vel'mocí iba potvrdzovalo nevyhnutnost' úzkej spolupráce v strednej Európe. Stredoeurópska federácia sa mala stat, podl’a Hodžu, nie spolkovým štátom, ale spolkom štátov. V tom bode sa zhodol s Naumannom: nie Bundestaat, ale Staatenbund.

Zaujímavé je porovnat niektoré závery, ktoré autori urobili v týchto troch dielach, ktoré sú, napriek zjednocujúcej téme, velmi rozdielne.

Prvou otázkou je koncepcia strednej Európy a Európy. Bolo jasné, že ako Masaryk, tak aj Naumann chápali, že budúcnost’ Európy bude závisiet’ od výsledku vojny. Naumann nazval svoje dielo „najmierumilovnejším dielom vojnovej publicistiky“. ${ }^{20}$ Popri nemeckom vítazstve vo vojne počítal Naumann s možnostou kompromisného mieru. Táto možnost sa mu zdala byt’ najreálnejšou. V takom prípade ale Nemecko nemohlo dosiahnut svoje svetovládne ciele a bude sa musiet’ orientovat̉ na kontinentálnu Európu. Stredoeurópska a európska hegemónia však mohla byt aj základným predpokladom prenikania Nemecka mimo Európu. Na druhej strane, podla Masaryka, nová Európa môže vzniknút iba za predpokladu, že Nemecko bude vo vojne porazené. Počas písania diela sa už nemecká porážka mohla črtat, ale ešte stále existovalo, po brestlitovskom mieri, riziko kompromisného mieru. Masaryk neveril, že Hohenzollernovci a Habsburgovci môžu byt̉ nositelmi

18 Hodža, Milan: Federácia v strednej Európe. A iné štúdie. Bratislava 1997.

19 Hodža, Milan: Federation in Central Europe. Reflections and Reminiscences. London 1942.

20 Jindra, Z.: Der Plan, s. 62. 
demokratickej premeny, preto vychádzal z ich porážky ako zo základného predpokladu vzniku novej Európy.

Rozdielne boli aj predstavy Masaryka, Hodžu a Naumanna o novej Európe. Podla Naumanna kontinentálna Mitteleuropa mala byt’ vel'kým súštátím, ktoré by mohlo politicky i ekonomicky konkurovat USA, Vel'kej Británii a Rusku, mala sa teda stat štvrtou svetovou vel'mocou (Weltstaat). ${ }^{21}$ Pre Naumanna bolo teda Francúzsko, Španielsko a Taliansko mimo možnosti hrat dôležitejšiu úlohu v svetovej politike.. Od Ruska sa mali odtrhnút pobaltské krajiny, ktoré sa tak mali stat’ satelitmi Mitteleuropy. Dánsko, Holandsko a Belgicko nespomína, ale z inej jeho publicistiky je jasné, že mali byt tiež súčastou tohto súštátia. Ked’že pôvodne išlo v Naumannovom diele iba o užšie spojenie Nemecka a Rakúsko-Uhorska, jeho iné predstavy možno odvodit iba od jeho d’alších komentárov. Tak podla Naumanna vzniknú v budúcnosti dve hrádze, dve vojenské hranice: medzi Mitteleuropou a Francúzskom a Mitteleuropou a Ruskom a malé štáty v tomto priestore si nebudú môct’ udržat svoju suverenitu. ${ }^{22}$ Mitteleuropa sa tak mala stat otvoreným systémom, lákavým pre malé štáty. Habsburská monarchia sa mala zachovat, ale ako nevyhnutné bolo treba pacifikovat’ odstredivé tendencie. Vyslovil sa ale aj za lepšie zaobchádzanie s národmi (Völker).

Podla Masaryka nová Európa sa mala stat jednotným duchovným a demokratickým systémom. Hlavným predpokladom tu mala byt zásadná demokratická reforma v Nemecku. Takáto premena Nemecka mohla nastat iba za predpokladu porážky Nemecka vo vojne a odstránenia Hohenzollernskej dynastie rovnako ako aj dynastie Habsburskej. Rusko sa mohlo vrátit do koncertu vel’mocí iba po páde bol’ševizmu. Za takého rozloženia síl po vítazstve Dohody bude stredná Európa mimoriadne dôležitým článkom novej Európy, čo si ale bude vyžadovat určitý čas, v ktorom ale nesmie dôjsț k recidíve nemeckého imperializmu. Podla Masaryka homo Europeus nezrodi sa pouze politikou vnějši, nýbrž hlavně vniterní. - všichni národové budou po válce nuceni všechno své smýšleni věnovat hmotné a duchovni obnově. ${ }^{23}$

Hodža ako jediný z trojice politikov zažil druhú svetovú vojnu a bol svedkom toho, čoho sa Masaryk obával: recidívy nemeckého imperializmu i vpádu bol'ševizmu do európskej a svetovej politiky. Vo svojom diele sa obmedzil na priestor strednej Európy, aj ked' tento priestor videl v širokých európskych dimenziách. Rešpektoval existenciu vel'mocí, ale pre strednú Európu videl ako nevyhnutnost’ politické spojenie, politickú i ekonomickú spoluprácu: Práve teraz vel'kej väčšine - v podstate všetkým - stredoeurópskym národom ich súčasná situácia dokazuje, že bezpečnost' im zaruči len porozumenie a spolupráca a že neochota spolupracovat' sa im stala osudnou. ${ }^{24}$

Zásadne sa Masaryk, Naumann a Hodža odlišujú pri hodnotení postavenia, úlohy a perspektív malých národov. Naumann celkom jednoznačne odsudzuje malé národy a malé štáty do úlohy štatistov, ktorí síce môžu byt formálne nezávislé, ale de facto vždy

21 Naumann, F.: Mitteleuropa, s. 4.

22 Tamtéž, s. 178.

23 Masaryk, T. G.: Nová Evropa, s. 222.

24 Hodža, M.: Federácia, s. 65. 
závisia od toho aké je rozloženie síl vel’mocí: „Všetci, ktori bojujú vo svetovej vojne cítia bezprostredne, že v súčasnom a budúcom svete malé a stredné mocnosti už nebudú môct' robit' vel'kú politiku...Duch vel'kých jednotiek a nadštátnych organizácii ovládol politiku...Kto chce ostat' malý a samostatný, bude napriek tomu závislý od zmeny postavenia vel’mocí. "25 Nielen v diele Mitteleuropa, ale aj v svojej d’alšej publicistike opakoval tento svoj názor, takže ho možno považovat’ za konštantu jeho politických ideí. Pre národy medzi Ruskom a Nemeckom používa Naumann termín „Zwischenvölker“ a nedáva im nijakú šancu na to, aby mohli byt’ samostatné a suverénne, pretože „musia existovat'vedúce národy a také, ktoré budú vedené ${ }^{\text {(26 }} \mathrm{V}$ tomto duchu sa niesla publicistika F. Naumanna už pred vojnou, a počas vojny sa pokúšal Naumann presviedčat malé národy, že usilovanie o štátnu samostatnost̉ a suverenitu nemá budúcnost'. V tomto bode sa názor Naumanna vel’mi priblížil názorom Všenemcov. Naumann sa však od Všenemcov odlišuje tým, že kladie dôraz na to, že Nemci, ak majú splnit svoju európsku misiu, musia byt’ voči malým národom ohladuplní a ústretoví. Potom bude nemecká hegemónia pre malé národy nielen znesitel'ná, ale naopak, výhodná. ${ }^{27}$

T. G. Masaryk v svojom diele Nová Evropa videl problém malých samostatných národov ako „dvojný proces: Osamostatněni menšich a malých národů neprotivi se tendenci vývoje, upevňujicího stále užši a užši spojeni mezistátni a mezinárodni; je pravda, jednotlivci a národové maji př́mo potřebu spojovat se s jinými a historie spěje $k$ organisací celého lidstva. Avšak tento historický vývoj je processem dvojným: zároveň s individualisací ve všech oborech tuži se organisace individuí..národové evropšti tou mèrou, jak se individualisuji, usiluji i o semknutí hospodářrké, komunikačni a vůbec se sbližuji po stránce technické kultury. ${ }^{28}$ Masaryk, ako je známe, už pred vojnou venoval v svojom diele vel'kú pozornost’ otázke malých národov, predovšetkým v dielach Česká otázka (1895) a Problém malého národa (1905). Bolo to prirodzené, sám bol súčastou českej politiky a českej kultúry, ktorá bola politikou a kultúrou malého národa. Zamýšlat sa nad tým aké je postavenie tejto politiky a kultúry znamenalo súčasne hl'adat zmysel existencie malých národov vôbec. Aj v memorande Independent Bohemia, hoci jeho vel'kú čast’ venoval práve dokazovaniu, že nový, československý štát nebude malým, ale stredným štátom, konštatoval, že malé národy a štáty majú svoj historický význam. Podl’a Masaryka je význam malých národov v kultúre neodškriepitel’ný, ale majú svoje poslanie aj v politike a v ekonomike, ale konštatoval, že malé národy majú tendenciu sa združovat. Predpokladom združovania sa je ale, podla Masaryka, sloboda. Čisto v teoretickej rovine nie je v tomto bode Masaryk d'aleko od Naumanna. Zásadný rozdiel je však v tom, že pre Masaryka malo vymedzovanie sa malých stredoeurópskych národov zmysel práve v tom, že sa vymedzujú voči vel'kému Nemecku. Masaryk bol vel'mi skeptický voči možnosti, že Nemecko sa pretvorí na demokratický štát bez imperialistických ambícií. Preto, na rozdiel od Naumanna, považoval za nevyhnutné pre európsku

25 Naumann, F.: Mitteleuropa, s. 92.

26 Jindra, Z.: Der Plan, s. 80.

27 Naumann, F.: Mitteleuropa, s. 178.

28 Masaryk, T. G.: Nová Evropa, s. 90. 
politiku, postavit hrádzu nemeckej rozpínavosti, jeho politike Drang nach Osten, ktorá bola za vojny vel'mi zretel’ná.

Milan Hodža už od začiatku svojej publicistickej a politickej činnosti velmi intenzívne vnímal problém malého národa a malého štátu. Počas prvej svetovej vojny sa stal stúpencom vytvorenia česko-slovenského štátu a po jeho vzniku bol významným československým politikom. Nemohol nevidiet problémy, ktoré stoja pred malým národom a malým štátom. Podobne ako Masaryk videl tento problém ako problém „dvojný“. Ak je národ individualitou, potom má právo na samostatnost’ a štát a to bez rozdielu na to, či ide o národ velký, alebo malý. Toto zásadné právo však nič nemení na situácii, že v ekonomike a v politike tažko môže byṫ malý štát úplne rovnoprávny so štátom velkým. Preto pre Hodžu je priamo životnou nevyhnutnostou pre malé národy, a konkrétne malé národy strednej Európy, národy medzi Ruskom a Nemeckom, aby sa spájali a tak tvorili silný celok, schopný odolat tlaku a agresii vel’mocí. Vývoj v medzivojnovej Európe a následná nemecká agresia, ktorá priviedla k druhej svetovej vojne, utvrdila v Hodžovi jeho presvedčenie, že pre všetky stredoeurópske národy je federalizácia nevyhnutnostou. Na otázku, či malé a stredné štáty, ktoré sa tak lahko stali obetou agresie majú šancu prežit a či sú vôbec hodné záchrany, odpovedá zásadne kladne, ale iba za predpokladu, že sa budú vediet’ dohodnút. Podla Hodžovho názoru, a možno to považovat za jeho politický testament, malé národy v strednej Európe môže zachránit iba úzka spolupráca na základe stredoeurópskej federácie. Na otázku, či malé národy majú právo a majú perspektívu prežit v budúcom svete, dáva Hodža jednoznačne pozitívnu odpoved’: „Každý národ, velký, stredný, či malý, má rovnaké právo žit', alebo, lepšie povedané, nijaká moc nemá právo zničit národ, nech je aj malý a slabý ${ }^{“ 29}$ Pre Hodžu takéto právo vyplýva z demokratického princípu. Na druhej strane ale, podla Hodžu, aj malé národy majú svoje povinnosti: „Každý národ, velký či malý, musi prežit a prežije len vtedy, ked' prispeje primeranou častou $k$ spoločným morálnym a materiálnym hodnotám ludstva “ ${ }^{\text {"30 }} \mathrm{A} \mathrm{v}$ pragmatickej politike môžu malé národy prispiet k celosvetovému porozumeniu tak, že napriek rozdielnej histórii a rozdielnym parciálnym záujmom nájdu spoločnú reč a dokážu sa federalizovat. Malé národy musia byt aktívne a tak obstát v konkurenčnom boji.

Otázkou, v ktorej sa traja politici najviac zbližujú, je otázka politického systému. Všetci traja sú, jednoznačne, stúpencami demokratického zriadenia. Naumann v svojom diele navrhuje vlastne v prvej fáze, splynutie vojnových spojencov: Nemecka a Rakúsko-Uhorska. Za vhodnejší variant považuje síce spolkový štát (Bundesstaat), ale vzhl’adom na konkrétnu situáciu navrhuje spojenie vo forme spolku štátov (Staatenbund). Centralizáciu považuje za potrebnú predovšetkým v ekonomických a hlavne v colných záležitostiach. Tak by vznikol systém, ktorý by zabezpečil vzájomnú prepojenost', ale dal súčasne jednotlivým štátom (a takým štátom by malo byt aj Uhorsko) možnost', aby si mnohé záležitosti riadili úplne samostatne. Je pochopitel'né, že v roku 1915 zdôraznil, že monarchia je nedotknutelná, ale spolok štátov by mal pozostávat z demokratických parlamentných monarchií. 
Demokratický systém je aj programom Masarykovým. Na konci vojny už mohol konštatovat, že program spojencov, teda Dohody, je programom demokratickým, ktorý vyplýva z humanitných ideálov. To mohol, samozrejme, konštatovat po tom, ako zo spojeneckého tábora vypadlo cárske Rusko. Ešte v roku 1915, v memorande Independent Bohemia, zvažoval možnost', že Československo vznikne ako parlamentná monarchia, dokonca rátal aj s možnostou, že panovníkom sa stane príslušník romanovskej dynastie. Teda v roku 1915 ešte Masaryk, rovnako ako Naumann, považoval za možnú existenciu parlamentnej monarchie v strednej Európe. Ku koncu vojny už Masaryk myšlienku monarchie opustil. Už vo Washingtonskej deklarácii je demokratická republika definovaná ako jediná možná forma budúceho československého štátu. V Novej Evrope, vzhl'adom na spojencov: Vel'kú Britániu a Belgicko, uznáva existenciu parlamentnej monarchie za možnú iba ako prechodnú formu historicky existujúcu v niektorých štátoch, ale nevhodnú pre nový demokratický štát. Demokraciu ale považuje za základný pilier existencie nového československého štátu. Uvedomoval si súčasne, že demokraciu nemožno jednoducho nastolit, ale že demokracia môže fungovat' iba potom, ked' sa stane všeobecným presvedčením, svetovým názorom občanov. ${ }^{31}$

Demokratický politický systém je východiskom všetkých politických úvah Milana Hodžu. Už v začiatkoch svojej politickej činnosti považoval demokraciu za základný princíp, ktorý môže riešit aj slovenskú otázku: „Potreby naše ženú nás do demokracie a bud’me ubezpečeni, že v tejto je najistejšia záruka našeho rozvoja i národného i hospodársko-spoločenského. "32 Pravda, v tom čase Hodža pod demokraciou rozumel predovšetkým všeobecné volebné právo. Bol presvedčený, že všeobecné volebné právo môže postupne oslabit a napokon zlikvidovat mad’arskú supremáciu v Uhorsku. Hodža ostal stúpencom demokracie aj po skúsenostiach z medzivojnového Československa a udalosti druhej svetovej vojny ho iba utvrdili, že budúcnost’ celej Európy je iba v demokracii. Podla neho európska bezpečnost́ nemôže stát iba na západnej demokracii, ale k nej musí byt pričlenená aj demokracia stredoeurópska. ${ }^{33}$ Hodža bol v svojom diele, pokial’ išlo o federáciu v strednej Európe, vel'mi dôsledný a vypracoval pre federatívny štát podrobnú ústavu a spôsob jeho fungovania. Stredoeurópska federácia sa mala skladat z ôsmych štátov, federálny parlament (kongres) mal pozostávat z delegátov jednotlivých štátov. Federalizované štáty mali dobrovol'ne odovzdat kompetencie federálnej vláde. Na čele federácie mal byt federálny prezident a federálny kancelár (predseda vlády). Federálnymi orgánmi mala byt spravovaná zahraničná politika, obrana, obchod a financie. V rámci federácie mala byt colná únia. Hodža vychádzal z presvedčenia, že predstavitelia jednotlivých stredoeurópskych krajín po skúsenostiach z druhej svetovej vojny budú ochotní pristúpit na nevyhnutné kompromisy a vzdat’ sa v závažných otázkach úplnej suverenity v prospech federálneho celku. V tom zmysle sa Hodža inšpiroval už skúsenostou, ktorá, samozrejme Masarykovi i Naumannovi chýbala.

31 Masaryk, T. G.: Nová Evropa, s. 222.

32 Hodža, Milan: K aktivite Slovenskej národnej strany. In: Hodža, Milan: Články, reči, štúdie. Sväzok I. Aktivita a demokratizm v slovenskej politike od r. 1898 do r. 1906. Praha 1930, s. 187. Článok bol pôvodne uverejnený v časopise Hlas (4. ročník, č. 1) v septembri 1901. 
Zaujímavé je aj porovnanie Masaryka, Naumanna a Hodžu v otázke nacionalizmu a národného štátu. Naumann bol predstavitelom nemeckého nacionalizmu v liberálne-demokratickom balení. Nadväzoval v svojom politickom myslení na idey Paulskirche a bol pri tom presvedčený o európskom a svetovom poslaní nemeckého národa, ktorého úlohou je organizovat nielen strednú Európu, ale Európu vôbec. Pokial' išlo o niektoré tzv. Zwischenvölker na východe, Nemecko, podla Naumanna malo vystupovat ako ich osloboditel' od ruského jarma. Podla Naumanna, ak má Nemecko splnit túto oslobodzujúcu misiu, musí sa stat štátom demokratickým. K tomu však potrebuje vnútornú prestavbu. Od úspešnosti tejto demokratickej reformy závisí aj kvalita vztahov medzi Nemcami a ostatnými národmi. Už v svojom diele z roku 1905 sa Naumann predstavil ako liberálny monarchista. ${ }^{34}$ Nacionalizmus Naumannov sa presadil predovšetkým tam, kde písal o jazyku a kultúre: „Mitteleuropa bude v jadre nemecká a bude celkom prirodzene použíuat nemecký svetový a sprostredkovaci jazyk, musi ale od prvého dña voči všetkým susedným jazykom preukázat ústretovost' a pochopenie, pretože iba tak môže vyrást' vel'ká harmónia, ktorá je nevyhnutná pre všestranne vybojovaný a zo všetkých strán obklúčený vel'koštát. ${ }^{\circledR 35}$ Naumann sa usiloval agitovat pre takýto velkoštát a ako ústupok navrhoval, aby sa hlavným mestom, kde by boli umiestnené všetky centrálne úrady, stala Praha. ${ }^{36}$

T.G.Masaryk bol v svojich politických začiatkoch kritikom českého nacionalizmu, ktorý operoval s programom „obnovy českej štátnosti“. Ako politický realista videl nereálnost’ takého programu. Situácia sa však zmenila vypuknutím svetovej vojny. Masaryk pochopil, že v prípade dlhotrvajúcej vojny je možné očakávat závažné zmeny v Európe. V prípade vítazstva Dohody mohli Česi a Slováci na troskách porazenej Habsburskej monarchie vybudovat svoj štát, teda národný štát národa československého. Zdanlivo to bol velký skok od predvojnovej politiky. Od kritiky „národného štátu“, až po boj za národný štát a vytýčenie hesla: Státy musi být znárodněny. ${ }^{37} \mathrm{~V}$ Masarykovom poňatí znárodnenie štátov znamenalo formovanie štátov národných. Takým štátom malo byt aj Československo. Pre Masaryka to však bola iba nevyhnutná fáza vo vývoji, ktorý mal d’alej smerovat k čoraz intenzívnejšej spolupráci národov a to nielen v strednej Európe, ale v Európe vôbec. Predpokladom takejto spolupráce je však dôsledná demokratická prestavba politických systémov: „Skutečná federace národů nastane teprve, až národové budou volni a sami se spojí. K tomu směruje vývoj Evropy. “"38 $\mathrm{V}$ tom duchu sa, podla Masaryka, mal budovat aj československý štát ako otvorený systém smerujúci k občianskemu štátu. V Novej Evrope sa táto idea ešte zretelne neformulovala, ale je v pozadí Masarykových úvah o strednej Európe a Európe: „Idea katolicity, všelidskosti, člověčenstva jako organisovaného celku, demokracii se neztratí. I demokracie doufá a pracuje $k$ tomu, aby byl jeden ovčinec a jeden pastýr “ ${ }^{39} \mathrm{~V}$ tomto

34 Naumann, Friedrich: Demokratie und Kaisertum. Berlin-Schöneberg 1905.

35 Naumann, F.: Mitteleuropa, s. 101.

36 Tamtéž, s. 242.

37 Masaryk, T. G.: Nová Evropa, s. 210.

38 Tamtéź, s. 88.

39 Tamtéž, s. 224. 
výroku možno vidiet aj parafrázu Naumannovej koncepcie Hirt und Heerde. Vývoj medzivojnovej Európy však mal iné smerovanie.

Milan Hodža považoval nacionalizmus za nevyhnutné štádium vo vývoji ludstva. Podobne to malo byt aj s národným štátom. Nevidel teda národ a národný štát ako definitívne štádium vo vývoji ludstva, ktorým by sa skončili dejiny. Národy však musia presiahnut samé seba: „Ak národnost’ naznačuje cestu plnenia morálneho záväzku voči l'udstvu, o čo ide modernému nacionalizmu? Pre l’udí, ktorí sa s touto povinnostou stotožnia a dovř́sia ju, znamená nacionalizmus nepochybne zodpovednost' za jej prevzatie. Demokratický nacionalista sa teda bude všemožne usilovat' rozvíjat’ osobitý potenciál národa a tak prispiet’ $k$ spoločnému cielu l'udstva. " ${ }^{40}$ V tom zmysle videl Hodža perspektívu strednej Európy i Európy vôbec. Znamenalo to súčasne radikálne odmietnutie Hitlerovej „Novej Európy“ a vôbec nemeckej koncepcie Lebensraumu, ktorá sa v nemeckej politike objavovala kontinuitne už od roku 1871.

U Masaryka, Naumanna a Hodžu teda nachádzame dobou podmienený nacionalizmus, ale zatial čo Naumann dospel iba do štádia demokratickej síce, ale Nemeckom ovládanej strednej Európy, Masaryk i Hodža ako predstavitelia malých národov hladali cesty $\mathrm{k}$ demokratickému a prirodzenému dorozumeniu národov.

Koncepcie a predstavy o usporiadaní strednej Európy u Masaryka, Naumanna a Hodžu sú rozdielne. Vznikali v rôznych historických obdobiach a vyjadrujú životné skúsenosti a politické presvedčenie svojich autorov. Vojna, prvá svetová, ale následne aj druhá svetová, vytvorili pre politické myslenie vhodné prostredie na to, aby bola spoločnost̉ náchylná na rôzne plány zmeny, rekonštrukcie a pod. Aj ked’ sa formovali po prvej svetovej vojne tzv. národné štáty, pre politikov i politológov, ktorí sa zamýšlali nad budúcnostou Európy a sveta bolo jasné, že politická transformácia musí prebehnút na širšej báze ako je národný štát. V tomto zmysle sú koncepcie Masaryka a Hodžu v mnohom kompatibilné, sú ale v zásadnom rozpore s koncepciou Naumana v jednej otázke: otázke vedúcej a dominantnej úlohy Nemecka v strednej Európe. Úvahy Masaryka, Naumanna a Hodžu sú historicky podmienené dobou svojho vzniku, môžu však byṫ produktívne pri úvahách o budúcnosti Európy aj v súčasnosti.

\section{The 'New Central Europe' of Tomáš G. Masaryk, Friedrich Naumann and Milan Hodža}

This study is a contribution to the lively discussion over the past twenty years comparing the ideas formed by T.G. Masaryk and Friedrich Naumann during the First World War. The author has expanded this discourse to include works by the Slovak politician, Milan Hodž, in particular his last work, Federation in Central Europe. The study is not limited to an analysis of the works of these three politicians, as it also attempts to place these works within a historical context, together with their political and journalistic activities. The author mainly focuses on comparing Masaryk, Naumann and Hodž's ideas about these key themes: the concept of Central Europe in Europe as such, political systems, democracy, the status and objectives of a small country and a small state, and

40 Hodža, M.: Federácia, s. 216. 
the place of nationalism and the national state within these political concepts. The author states that all three politicians agreed that Europe in the future had to be democratic, but their specific ideas about its character differed, as Naumann's plan was to create a democratic Central Europe under German leadership, which Masaryk and Hodža refused outright. This was the same case for the concept of the nation state and supranational institutions. While Masaryk wanted a gradual expansion of the cooperation between nations and states, Hodža had envisaged a specific Central European federation, whereas Naumann, unlike Masaryk and Hodža, did not see any future for small nations and states, envisaging instead the future of continental Europe under German domination. 